\title{
EFFECT OF USING GUAVA AND GRAPE SEEDS EXTRACTS ON OXIDATIVE STABILITY OF BLENDED SUNFLOWER AND SOYBEAN OILS
}

\author{
Talaat M.A. El-Kady ${ }^{1 *}$, A.O. Toliba ${ }^{2}$, M.K. Abd El-Rahman ${ }^{1}$ and S.M. Abo El-Maati ${ }^{2}$ \\ 1. Nat. Nut. Inst., Minist. Health, Cairo, Egypt \\ 2. Food Sci. Dept., Fac. Agric., Zagazig Univ., Egypt
}

Received: 27/12/2016 ; Accepted: 22/03/2017

\begin{abstract}
This study was performed to evaluate the effect of guava seeds (GVSE) and grape seeds (GRSE) extracts compared to butylated hydroxytoluene (BHT) on the antioxidant activity of blended sunflower and soybean oils $(1: 1 \mathrm{~V} / \mathrm{V})$, defined as $\mathrm{BO}$ at $70^{\circ} \mathrm{C}$ for $72 \mathrm{hrs}$. GVSE and GRSE were separately added to the blended oils at two different concentrations (200 and $500 \mathrm{ppm})$. Synthetic antioxidant BHT at ratio of $200 \mathrm{ppm}$ was used as positive control with the blends oils. The oxidative assessments were Peroxide value, $P$ - anisidine value, total oxidation value and thiobarbituric acid reactive substances were used for measuring the oxidative stability of these blended oils. Results showed that the highest level of GVSE and GRSE gave the best protection against primary and secondary oxidation of blended oil samples. The high efficiency of these extracts was observed as follows: 500 ppm GRSE > 500 ppm GVSE > 200 ppm BHT > 200 ppm GRSE > 200 ppm GVSE > control. Therefore, some of food processing wastes could be used as natural antioxidant in edible oils manufacturing.
\end{abstract}

Key words: Guava seeds, grape seeds, blended oils, sunflower oil, soybean oil, oxidative stability.

\section{INTRODUCTION}

In the food processing industry, edible portions of fruits are processed into products such as puree, canned slices and juice. Ajila et al. (2007) noted that, the use of fruit seeds for commercial purposes, especially as antioxidants remains low due to their lack of popularity and lack of scientific work. Soong and Barlow (2004) mentioned that fruit seeds demonstrate significantly higher total antioxidant capacity and phenolic content than the edible portions. This statement was further supported by Okonogi et al. (2007) who reported that the peel and seed fractions of some fruits have higher antioxidant activity than the pulp fraction. Such studies have directly shown the high potential of seeds for using as sources of natural antioxidants.
Common guavas (Psidium guajava) are an important tropical and semitropical fruit mainly consumed fresh. The main processed products of guava fruits products are beverages, juices, and canned slices. The seeds are the waste product of these industries and are not yet used for any beneficial purpose (Sanda et al., 2011). The seeds are thrown in landfills that may present environmental load.

Grapes (Vitis vinifera L.) are the world's largest fruit crop (Ghafoor et al., 2010) with a total production of approximately 75.1 million tons in 2013 (OIV, 2015). Grape is a wildly spread fruit crop in Egypt, it is considered to be the second most important fruit crop after citrus fruit. The majority of grapes in Egypt originate from the species (Vitis vinfera L.). Egypt produces 1.37 .815 tons of grapes (FAOSTAT, 2012).

\footnotetext{
* Corresponding author: Tel. : + 201201365133
}

E-mail address: talaat_nni5@yahoo.com 
The amount of bio-waste produced by the food industry annually in the European Union is estimated by $35,000,000$ tons (Commission of the European Communities, 2011) (El-Baroty et al., 2014). In Egypt, the food and agricultural industries produce large quantities of waste and/or by-products, causing the biggest serious disposal problem. The most of agro-wastes are either allowed to decay naturally on the fields or burned or used as low quality compost or animal feed without segregation or significant treatment. Therefore, from economic and environmental view point, treating of these agricultural wastes and agro-industrial to produce high value by-products is desirable (Nandeesh et al., 2011).

Oxidation of unsaturated lipids is a major cause of food quality deterioration by giving rise to the development of off-flavour compounds, loss of nutritional value of food products and even the formation of potentially toxic compounds producing non healthy products (Cadwallader and Howard, 1998).

Food antioxidants are compounds or substances that are present naturally in some ingredients or are intentionally added as food additive (natural or synthetic) with the aim of inhibiting the product oxidation (Halliwell, 1996). The detrimental effects of excessive lipid oxidation such as formation of off-flavours and undesirable oxidized chemical compounds (aldehydes, ketones and organic acids) are well known (Saad et al., 2007).

Propyl gallate, Tert-butylhydroquinone (TBHQ), Butylated hydroxyanisole (BHA) and Butylated hydroxytoluene (BHT)) are widely used as synthetic antioxidants, but their application has been reassessed because of possible toxic or carcinogenic components formed during their degradation (Pitchaon et al., 2007). Due to these safety concerns, there is an increasing trend of food scientists to replace these synthetic antioxidants by natural ones, which are supposed to be more safety (Yanishlieva and Marinova, 2001).

Phenols are one of the most important groups of natural antioxidants (Artajo et al., 2006). Natural antioxidants are more ideal as food additives, not only for their free radical scavenging properties, but also on the belief that natural products are healthier and safer than synthetic ones; thus, they are more readily acceptable to the consumers. The main classes of natural antioxidant compounds in nature are flavonoids and phenolic acids in free or complexed forms. These compounds have been identified and quantified in several fruits and vegetables, and show a high correlation with antioxidant activity (Einbond, 2004).

Lipid oxidation is the main deterioration process occurred during thermal processing of vegetable oils containing lipid molecules with polyunsaturation (El-Anany, 2007). Sunflower oil (seeds of Helianthus annuus L.) is widely used in nutrition as a source of essential linoleic (9-cis, 12-cis-octadecadienoic acid). According to USDA report, soybean oil is the second largest vegetable oil produced in the world. Soybean oil contains a high level of unsaturated fatty acids and a significant amount of omega-3 fatty acids (Zambiazi et al., 2007), which is considered as part of the healthy fat group. They are also the cause of the oxidative instability of this oil (Frank, 2011).

Blended oils are gaining popularity world wide due to the advantages they offer such as improved thermal and oxidative stabilities, nutritional benefits (Sharma et al., 1996) and an ability to tailor the desired properties. Most importantly, they are cheap alternatives or substitutes to pure vegetable oils. Blending different kinds of vegetable oils not only can change fatty acids profile, but also increase the levels of bioactive lipids and natural antioxidants in the blends improving their quality and their nutritional value with affordable prices (Aladedunye and Przybylski, 2013).

This study was carried out to evaluate the antioxidant activity of Guava and Grape seeds extract. They were used under accelerated oxidation conditions of blended sunflower and soybean oils (BO) at $70^{\circ} \mathrm{C}$ for $72 \mathrm{hr}$., measuring its oxidative stability compared with synthetic antioxidant, BHT (+ve control) and negative control (blended oil without antioxidants).

\section{MATERIALS AND METHODS}

\section{Materials}

Guava (Psidium guajava) and grape (Vitis vinifera $\mathrm{cv}$. Red roomy) were purchased from 
Egyptian local market, Cairo, Egypt. Refined, bleached and deodorized (RBD) sunflower oil (SFO) and soybean oil (SBO) were obtained from Tanta Company for oil and soap, Tanta, Egypt. The oils were free from any antioxidants. All the chemicals and reagents were analytical grade and purchased from Sigma-Aldrich (Sigma Chemical, St. Louis, Missouri, USA).

\section{Methods}

\section{Fruit seeds preparation}

Guava and grape seeds were removed manually and separated from the pulp, then washed with excess water to remove adhering materials. Guava and grape seeds(moisture content were $11.3 \%$ and $13.2 \%$ respectively) were manually spread in a thin layer for drying at $40^{\circ} \mathrm{C}$ for 24 hours using electric oven (pSelecta, model 2000201, Spain). Grape seeds were heated in an oven at $100^{\circ} \mathrm{C}$ for $10 \mathrm{~min}$ according to Kim et al. (2006) converted to powder using grinder (Braun, Model 1021, Germany). Guava seeds were roasted in an oven at $150^{\circ} \mathrm{C}$ for $10 \mathrm{~min}$ according to El- Anany (2015). The roasted seeds were allowed to cool at room temperature before milling. Powdered seeds were stored in glass bottles at $4^{\circ} \mathrm{C}$ for further analysis (Mariod et al., 2012).

\section{Fruit seeds extract preparation}

According to the extraction method of ElAnany (2015), ten grams of fruit seeds powder were extracted overnight with $1000 \mathrm{ml}$ of $80 \%$ ethanol solution in a shaking incubator $(100$ rpm) at room temperature. Then the extracts were centrifuged (p-Selecta, model F04001, Spain) at $3500 \mathrm{rpm}$ for $15 \mathrm{~min}$. The supernatants were filtered through a Whatman No. 1 filter paper. The extract solutions were concentrated until their drying (moisture content $2.1 \%$ ) using rotary evaporator (Buchi, model R144, Italy) at $40^{\circ} \mathrm{C}$ and stored at $-20^{\circ} \mathrm{C}$ for further use.

\section{Sample preparation for accelerated storage}

Before fortifying the blended oil with the antioxidants, both of seeds extracts and synthetic antioxidant were dissolved in ethanol.

The blended oil (1:1 $V / V$ sunflower oil and soy bean oil) with fortified with two different concentrations for each of Guava seeds (GVSE) and Grape seeds (GRSE) extracts i.e.; 200 ppm and $500 \mathrm{ppm}$, while BHT was added by only one concentration; $200 \mathrm{ppm}$ and used as positive control. After the fortification with the antioxidants (natural and synthetic), the solvent (ethanol) was evaporated at $40^{\circ} \mathrm{C}$ using a rotary evaporator, then the bottles were sealed and subjected to the accelerated oxidation conditions at $70^{\circ} \mathrm{C}$ during $72 \mathrm{hrs}$., (as storage time) in the dark. The oxidative parameters (Gvse, Grse and BGHT, P V, $P$-an, TOTOX Value and TBARS) were determined every $8 \mathrm{hrs}$ during the storage period (72 hrs).

\section{Chemical Composition of Seeds}

Moisture, protein, ash, crude fiber and ether extract were determined according to AOAC (2005) methods.

\section{Antioxidant Activity}

\section{Total phenolic content}

Total phenolic contents of the extracts were measured using the Folin-Ciocalteu assay developed by Singleton and Rossi (1965). Aqueous Folin- Ciocalteu reagent $(1: 10, V / V)$ was added to the plant extract or standard, incubated for $5 \mathrm{~min}$ before addition of $0.115 \mathrm{mg} /$ $\mathrm{ml}$ of $\mathrm{Na}_{2} \mathrm{CO}_{3}$. After $2 \mathrm{hr}$., incubation period in the dark, absorbance readings at $765 \mathrm{~nm}$ using a UV-Vis spectrophotometer (Unicam, Helios Alpha, UK). Gallic acid was used as a standard and a calibration curve was plotted in a concentration range of 50-200 mg/l. The results were expressed as $\mathrm{mg}$ of Gallic acid equivalent/ g dry basis.

\section{Flavonoid content}

Flavonoid content was measured according to the method described by Zhishen et al. (1999). Each extract solution (5 ml) was mixed with $0.3 \mathrm{ml}$ of $5 \%$ aqueous $\mathrm{NaNO}_{2}(W / V)$ and allowed to stand at room temperature $\left(25^{\circ} \mathrm{C} \pm 2\right)$ for $5 \mathrm{~min}$; then $0.6 \mathrm{ml}$ of $10 \% \mathrm{AlCl}_{3}$ solution $(W / V)$ was added to the mixture. After 6 min, 2 $\mathrm{ml}$ of $1 \mathrm{M} \mathrm{NaOH}$ and $2.1 \mathrm{ml}$ of water were added to the mixture. The absorbance readings were recorded at $510 \mathrm{~nm}$ using spectrophotometer (Unicam, Helios Alpha, UK). The results were expressed as mg quercetin (Q) equivalent /100 g dry basis.

\section{Identification and quantification of phenolic compounds of seeds}

Phenolic acids of guava and grape seeds extracts were identified according to the method 
El-Kady, et al.

described by Mattila et al. (2000). The phenoilc compounds were determination by HPLC, using LC-10AT liquid chromatograph (LC; Shimadzu, Japan) equipped with C-18 column (300 4.6 $\mathrm{mml}$ Thermo Hypersil) and methanol : water (60 $: 40, V / V)$ as a mobile phase with a flow rate of 1 $\mathrm{ml} /$ min. Ultraviolet (UV) detection was carried out with a diode array detector (Shimadzu). The separation was carried out with methanol and acetonitrile as a mobile phase at flow rate of 1 $\mathrm{ml} / \mathrm{min}$. The column temperature was kept at $\left(35^{\circ} \mathrm{C}\right)$ throughout the experiment. Identification and quantification were carried out based on calibrations of the standards prepared from phenolic acids dissolved in a mobile phase.

\section{DPPH radical scavenging}

The DPPH method was determined as described by Yang et al. (2009) with some modifications. Briefly, $0.1 \mathrm{ml}$ of extracts (100 $\mu \mathrm{g} / \mathrm{ml}$ in methanol) was added to $3.9 \mathrm{ml}$ of 0.2 $\mathrm{mM}$ DPPH methanolic solution. The reaction mixture was agitated and allowed to stand at room temperature $\left(25^{\circ} \mathrm{C} \pm 2\right)$ in the dark for 30 min. The absorbance was reading at $515 \mathrm{~nm}$ using a spectrophotometer (Unicam, Helios Alpha, UK). BHT $(100 \mu \mathrm{g} / 1 \mathrm{ml}$ in methanol) was used as a positive control. The inhibition percentage of the DPPH radical was calculated according to the following equation:

Inhibition $(\%)=(($ A control $-\mathrm{A}$ sample $) / \mathrm{A}$ control $) \times 100$

Where: $\mathrm{A}$ is absorbance

\section{Reducing power}

The reducing power of extracts was measured as described by Oyaizu (1986). The mixture containing $1.0 \mathrm{ml}$ of extract, $1.0 \mathrm{ml}$ of $0.2 \mathrm{M}$ phosphate buffer ( $\mathrm{pH} 6.6)$ and $1.5 \mathrm{ml}$ of potassium ferricyanide $(1 \%, W / V$, in water) was incubated at $50^{\circ} \mathrm{C}$ for $30 \mathrm{~min}$. The reaction was stopped by addition of $1.5 \mathrm{ml}$ of trichloroacetic acid $(10 \%, W / V$, in water), followed by a centrifugation at $980 \mathrm{rpm}$ for $10 \mathrm{~min}$. Aliquots of $2 \mathrm{ml}$ of the supernatant were mixed with $2 \mathrm{ml}$ of distilled water and $0.5 \mathrm{ml}$ of ferric chloride $(0.1 \%, W / V$, in water) then the absorbance was recorded at $700 \mathrm{~nm}$, using a spectrophotometer (Unicam,Helios Alpha, UK), compared to blank sample which contains only all the used reagents.

\section{Ferric Reducing Antioxidant Power (FRAP) Assay}

The FRAP assay of the extracts was carried out according to the procedure of Benzie and Szeto., (1999). One hundred micro liters of the extract ( $1 \mathrm{~g} \mathrm{du}$ : $50 \mathrm{ml}$ of $80 \%$ ethanol) was added to $3 \mathrm{ml}$ of the FRAP reagent. After $4 \mathrm{~min}$, the absorbance readings were recorded at $593 \mathrm{~nm}$ using UV/VIS spectrophotometer (Unicam, Helios Alpha, UK). A calibration curve was prepared using BHT as a standard at 200, 400, 600,800 and $1000 \mu \mathrm{M}$. FRAP values were expressed as ( $\mu \mathrm{M}$ BHT equivalent/g dry basis).

\section{Oxidative Stability of Blended Oil}

\section{Peroxide value (PV)}

The peroxide value (PV) was determined according to the method of AOAC method (2005). Blended oil samples of $5.00 \mathrm{~g}$ were dissolved in $30 \mathrm{ml}$ acetic acid-chloroform solution $(3: 2, V / V)$. After that, $1 \mathrm{ml}$ of saturated KI was added. The mixture was allowed to stand with occasional shaking for one minute and kept in the dark for $5 \mathrm{~min}$. This step was followed by addition of $30 \mathrm{ml}$ distilled water. The mixture was titrated against sodium thiosulfate $(0.002$ M) until the yellow colour almost disappeared. Then, about $0.5 \mathrm{ml}$ of $1 \%$ starch solution was added. The titration continued until the blue colour disappeared. A blank was also analyzed under the same conditions. The peroxide value was calculated according the equation:

Peroxide value $(\mathrm{PV})=[\mathrm{S} \times \mathrm{M} \times 1000] /$ sample weight $(\mathrm{g})$

Where, $\mathrm{S}$ is the value of $\mathrm{Na}_{2} \mathrm{~S}_{2} \mathrm{O}_{3}$ used (blank corrected); $\mathrm{M}$ is the molarity of $\mathrm{Na}_{2} \mathrm{~S}_{2} \mathrm{O}_{3}$.

\section{Measurement of $\boldsymbol{p}$-Anisidine value ( $P$-an)}

The $p$-Anisidine value $(P$-an) was determined according to AOCS method (2007). Blended oil samples $(2 \mathrm{~g})$ were dissolved in $25 \mathrm{ml}$ of isooctane and the absorbance was recorded at $350 \mathrm{~nm}$. After that, $5 \mathrm{ml}$ of the above mixture were mixed with $1 \mathrm{ml}$ of $0.25 \% p$-anisidine in acetic acid $(W / V)$ and allowed to stand for 10 min. lastly; absorbance was read again at 350 $\mathrm{nm}$. The $P$ - an values were calculated using the equation:

$p$-Anisidine value $=$ 
$25 \times\left[1.2 \mathrm{~A}_{\mathrm{s}}-\mathrm{A}_{\mathrm{b}}\right] /$ sample weight $(\mathrm{g})$

Where:

$\mathrm{A}_{\mathrm{s}}$ is the absorbance of test solution after reaction with the $p$-anisidine reagent; $A_{\mathrm{b}}$ is the absorbance of the fat solution.

\section{Total oxidation (TOTOX) values}

Total oxidation (TOTOX) value of the oil samples was determined according to Nyam et al. (2013).

TOTOX value was calculated using the following equation:

$$
\text { TOTOX }=2 \mathrm{PV}+P \text {-an } \mathrm{V}
$$

Where:

$\mathrm{PV}$ is the value of peroxide value; $P$-an is the value of $p$-anisidine value.

\section{Thiobarbituric acid reactive substances (TBARS)}

The Thiobarbituric acid test is based on the colour reaction of TBA with malondialdehyde (MDA) $\mathrm{mg} / \mathrm{kg}$ oil sample (David, 1970). The reading was recorded at $531 \mathrm{~nm}$ compared to blank sample (distilled water). A standard curve of MDA was prepared using 1, 1, 3,3tetraethoxypropane. TBARS values were expressed as mg of MDA per $\mathrm{kg}$ of sample.

\section{RESULTS AND DISCUSSION}

\section{Chemical Compositions of Guava and Grape Seeds}

The results in Table, 1 show chemical composition of GVS and GRS powder. From Table 1 it could be observed that, there were significant $(\mathrm{p}<0.05)$ differences among the studied seeds in their contents of crude protein, crude lipids, crude fiber, ash and carbohydrate. Guava seeds contained significantly $(\mathrm{p}<0.05)$ higher levels of protein, fat and fiber than grape seeds, which reflect the importance of such seeds for oil production. Also, from the same Table it could be noticed that, guava seeds had the highest amount of crude fiber (64\%) therefore; guava seeds could be considered as a good source of dietary fiber. While grape seeds contained significantly $(p<0.05)$ higher levels of ash and carbohydrate than guava seeds powder. These results are in agreement with those reported by Mohamed et al. (2011). On the other hand, Fontanari et al. (2008) reported that protein content of guava seeds was $9.2 \pm 0.10 \%$.

Table 2 shows that the yields of guava and grape seeds extracts were 5.3 and $17.23 \%$ on dry basis, respectively. The yield of GRSE extract was 3.2 times that of GVSE. Jung et al. (2006) found that the ethanol extracts contained higher amounts of total phenolic and flavonoids than water and methanol extracts from wild ginseng leaves. Gallegos-Infante et al. (2010) attributed this increase to the release of bound phenolics from the breakdown of cellular constituents during thermal treatment.

\section{Total phenolic content}

Polyphenols are phytochemicals from plants and used for prevention of various diseases mainly caused by free radicals. The higher polyphenol content would then exhibit stronger inhibition and higher antioxidant activity (Jayaprakasha et al., 2003). Table 2 shows that, total phenolic content of the extracts from guava and grape seeds were 1.39 and $24.71 \mathrm{mg} \mathrm{GAE} / \mathrm{g}$ dry basis, respectively. This means that the phenolic compounds in grape seeds about 17 times compared to the seeds of guava. The obtained results of total phenolic content for guava seeds and grape seeds extracts were in agreement with those reported by CastroVargas et al. (2010) and Poudel et al. (2008), respectively. Also, they found that Japanese grapes contained $3.60-54.90 \mathrm{mg} \mathrm{GAE} / \mathrm{g}$ dry weight. The Algerian grape seeds contained 38.92- $86.51 \mathrm{mg}$ GAE $/ \mathrm{g} \mathrm{dw}$ (Adrar et al., 2015). These variations in the phenolic content of grape seeds is dependent on genotypes, agricultural practices and extraction procedures (Xu et al., 2010).

\section{Total flavonoids content}

Flavonoids are the most common and widely distributed group of plant phenolic compounds (Guo et al., 2012) and are generally categorized as phenolics depending on their chemical structure (Sung and Lee, 2010). Table 2 shows that, the total flavonoids content of grape seeds (60.54 $\mathrm{mg} \mathrm{CE} / \mathrm{g} \mathrm{dw}$ ) was significantly higher than that of guava seeds $(5.9 \mathrm{mg} \mathrm{CE} / \mathrm{g} \mathrm{dw})$. The total flavonoids content varied according to extracting methods and sources of seeds. Total flavonoids and their antioxidant activity as well 
El-Kady, et al.

Table 1. Proximate composition of guava and grape seeds powders $(\mathrm{g} \backslash \mathbf{1 0 0 g})$ dry basis

\begin{tabular}{lcc}
\hline Component & Guava seed powder & Grape seed powder \\
\hline Moisture & $6.2 \pm 0.25^{\mathrm{b}}$ & $6.9 \pm 0.35^{\mathrm{a}}$ \\
Protein & $11.2 \pm 0.4^{\mathrm{a}}$ & $8.2 \pm 0.3^{\mathrm{b}}$ \\
Fat & $14.1 \pm 0.4^{\mathrm{a}}$ & $8.1 \pm 0.2^{\mathrm{b}}$ \\
Fiber & $64 \pm 3^{\mathrm{a}}$ & $32.9 \pm 1.8^{\mathrm{b}}$ \\
Carbohydrate & $3.2 \pm 0.25^{\mathrm{b}}$ & $35.1 \pm 1.65^{\mathrm{a}}$ \\
Ash & $1.3 \pm 0.1^{\mathrm{b}}$ & $2.3 \pm 0.15^{\mathrm{a}}$ \\
\hline
\end{tabular}

Means in a row followed by the same letter are not significantly different according to Duncan's multiple range test at $\mathrm{P}<0.05$. Data obtained from at least three replicates.

Table 2. Yield of extract, total phenolic content and total flavonoids content of the fruits seeds extracts

\begin{tabular}{lcc}
\hline Item & Guava seeds & Grape seeds \\
\hline Yield (\%) (g/100 g) & $5.3 \pm 0.205^{\mathrm{b}}$ & $17.230 \pm 0.57^{\mathrm{a}}$ \\
Total phenolics (mg Gallic/ g dw) & $1.39 \pm 0.05^{\mathrm{b}}$ & $24.717 \pm 1.21^{\mathrm{a}}$ \\
Total flavonoids (mg catechin /g dw) & $5.9 \pm 0.2^{\mathrm{b}}$ & $60.540 \pm 2.80^{\mathrm{a}}$
\end{tabular}

Means in a row followed by the same letter are not significantly different according to Duncan's multiple range test at $\mathrm{P}<0.05$. Data obtained from at least three replicates.

as their effects on human nutrition and health have been reported by Kessler et al. (2003). The mechanisms of action of flavonoids are through scavenging or chelating process.

The amount of carotenoids present in the powder sample obtained from the guava seed was $1.25 \pm 0.14 \mathrm{mg} / 100 \mathrm{~g}$ (Uchoa-Thomaz et al., 2014).

\section{Antioxidant Activity}

The free radical DPPH, of purple coloration that absorbs at $515 \mathrm{~nm}$, is one of the most widely used for in vitro evaluation of plant extracts and fractions. The results in Table 3 show that, the DPPH radical-scavenging activity of GVS and GRS extracts ranged from $89.3 \%$ to $94.26 \%$. The radical-scavenging activity of ethanol extract of grape seed $(100 \mathrm{ppm})$ was $(94.26 \%)$ not significantly different from that of the ethanolic guava seeds extract, ascorbic acid and BHT. The results of guava seeds are in agreement with those reported by Mohamed et al. (2011). However; it was higher than those obtained by Mansour and Khalil (2000). This difference might be due to the interspecies variation.

The ferric reducing antioxidant power (FRAP) assay was used to evaluate antioxidant capacities of the seeds. The FRAP assay is based on the capacity of antioxidants to reduce ferric (III) ions to ferrous (II) ions (Benzie and Szeto, 1999), The FRAP values of the seeds extracts are shown in Table 3 . The highest FRAP value recorded for grape seeds extract $(3452 \mu \mathrm{mol} \mathrm{Fe}$ (II) $/ \mathrm{g})$, followed by guava seeds $(2412 \mu \mathrm{mol} \mathrm{Fe}$ (II)/g). Wojdylo et al. (2007) reported that herbs can be classified according to their antioxidant capacity as very low FRAP $(<10 \mu \mathrm{M} / 100 \mathrm{~g})$, low FRAP (10-50 $\mu \mathrm{M} / 100 \mathrm{~g})$, good FRAP (50$100 \mu \mathrm{M} / 100 \mathrm{~g})$, high FRAP $(100-500 \mu \mathrm{M} / 100$ g) and very high FRAP $(>500 \mu \mathrm{M} / 100 \mathrm{~g})$.

The values of absorbance at $700 \mathrm{~nm}$ for the extracts of fruit seeds in Table_3revealed that all samples had a capacity to reduce iron (III), and the reducing power (RD) RP values of both seeds extracts were significantly different, ranging from 0.31 to 0.66 . The RP of grape seed extract was significantly higher than that of guava seeds extract and BHT. 
Table 3. Antioxidant activity of GVSE and GRSE

\begin{tabular}{lcccc}
\hline Item & Guava seed & Grape seed & BHT & Ascorbic acid \\
\hline DPPH Inhibition (\%) (100 $\boldsymbol{\mu l} / \mathbf{m l}) \mathbf{1 0 0} \mathbf{~ p p m}$ & $89.66 \pm 3.8^{\mathrm{b}}$ & $94.26 \pm 2.4^{\mathrm{ab}}$ & $94.9 \pm 2.7^{\mathrm{ab}}$ & $91.53 \pm 3.3^{\mathrm{ab}}$ \\
FRAP value ( $\boldsymbol{\mu m o l}$ BHT equivalent/g) & $2428.66 \pm 84^{\mathrm{b}}$ & $3452 \pm 126^{\mathrm{a}}$ & - & - \\
Reducing power $(\mathbf{a b s o r b a n c e}$ at $\mathbf{7 0 0} \mathbf{~ n m})$ & $0.31 \pm 0.02^{\mathrm{c}}$ & $0.66 \pm 0.01^{\mathrm{a}}$ & $0.36 \pm 0.03^{\mathrm{b}}$ & - \\
\hline
\end{tabular}

* Means in a raw followed by the same letter are not significantly different according to Duncan's multiple range test at $\mathrm{P}<0.05$. Data obtained from at least three replicates.

\section{Identification of Phenolic Compounds}

High performance liquid cormotograph (HPLC) is the preferred technique for both separation and quantification of phenolic compounds (Naczk and Shaidi, 2004). HPLC analysis of the phenolic compounds in guava, grape seeds extracts were compiled in Table 4, the results showed that the alcoholic extract of guava seeds was characterized by high levels of chlorogenic, vanillic, caffeine, ferulic acid and tannins.On the other hand, the alcoholic extract of grape seeds had nine compounds of phenolic which record the high contents of gallic acid, caffeic acid, catechin, coumaric, rutin and rosmarinic. Rodtjer et al. (2006) showed that the extraction yield of phenolic compounds is greatly depending on the solvent polarity. The differences in composition presented between the extracts reported in the literature and in the present study may be due to variety, degree of ripeness of the fruit used and the method of extraction. An important factor is the solvent used for the extraction of phenolic compounds, because solvents with different polarity extracted different compounds in varying quantities (Laguerre et al., 2011).

\section{Peroxide Value (PV)}

Hydroperoxide is the primary oxidation product produced as a result of lipid oxidation. It may break down into nonvolatile and volatile secondary products, which decrease the quality of the oil. This is an indicator of the initial stage of oxidative changes (Erwin et al., 2004). The presence of hydroperoxide in the oil can be determined based on the oxidation of iodine ion with hydroperoxide.

In this study, oxidation degree of blended oil (BO) samples was determined by measuring PV during accelerated oxidative storage of blended oil samples (with or without synthetic antioxidant or natural fruit seed extracts) at $70^{\circ} \mathrm{C}$ for $72 \mathrm{hr}$., as shown in Fig. 1 a,b. The results showed a continuous increase in $\mathrm{PV}$ with the increase of storage time for all the oil blend samples. Initially, the rate of PV was very slow, but it started to increase after $40 \mathrm{hr}$ of storage and went on increasing further with the increase in storage time $(72 \mathrm{hr}$.). Peroxide values were in the range of $0.05-17.7$ meq. $\mathrm{O}_{2} / \mathrm{kg}$ for oil blended contained GVSE, whilst they were from 0.05 to16.62 meq. $\mathrm{O}_{2} / \mathrm{kg}$ for oil blended contained GRSE. PV of the control (-ve) oil sample (without added antioxidant) did not exceed 19.53 meq. $\mathrm{O}_{2} / \mathrm{kg}$ after $72 \mathrm{hr}$., of storage at $70^{\circ} \mathrm{C}$. Results in Fig 1(a,b): show the development of $\mathrm{PV}$ during the storage of $\mathrm{BO}$ at $70^{\circ} \mathrm{C}$ for $72 \mathrm{hr}$,, with various concentrations of GVSE and GRSE extracts and BHT. Results indicated that PV of control sample exceeded the maximum level (10 meq. $\mathrm{O}_{2} / \mathrm{kg}$ oil) of the Egyptian Standard for Edible Oils after only $40 \mathrm{hrs}$., of heating at $70^{\circ} \mathrm{C}$.GVSE extract at a level of 200 or $500 \mathrm{ppm}$ had the same antioxidant effect of $200 \mathrm{ppm}$ BHT. They retard the increase of peroxide value of oil to the maximum permissible limit upon heating to $48 \mathrm{hrs}$. Data show that GRSE extract at levels of 200 and $500 \mathrm{ppm}$ exhibited high antioxidant efficiency than GVSE extract at the same levels or BHT at $200 \mathrm{ppm}$. Continual heating of oil blend to $72 \mathrm{hrs}$., was accompanied by an increase of PV to a higher unacceptable levels regardless type of extract and level of addition.

\section{$P$-Anisidine Value ( $p$-anV)}

During lipid oxidation, hydroperoxides, the primary reaction products, decompose to produce secondary oxidation products (aliphatic aldehydes, ketones, alcohols, acids and hydrocarbons) which 
Table 4. Phenolic compounds contents ( $\mathrm{mg} / 100 \mathrm{~g}$ dry matter) of guava and grape seeds extracts

\begin{tabular}{|c|c|c|c|c|c|c|c|c|c|c|c|c|}
\hline Seeds & Gallic & Chlorogeni & Caffeic & Vanillic & Catachin & Caffeine & Coumaric & Rosmarinic & c Rutin & $\begin{array}{c}\text { Ferulic } \\
\text { acid }\end{array}$ & Cinnamic & $\overline{\text { Tannins }}$ \\
\hline Guava seeds & - & 124.33 & - & 222.66 & - & 118 & - & - & - & 238 & 420 & 148.6 \\
\hline Grape seeds & 218 & 365 & 4.83 & 163 & 18.26 & - & 112.3 & 214.3 & 478.3 & 704.33 & - & - \\
\hline
\end{tabular}
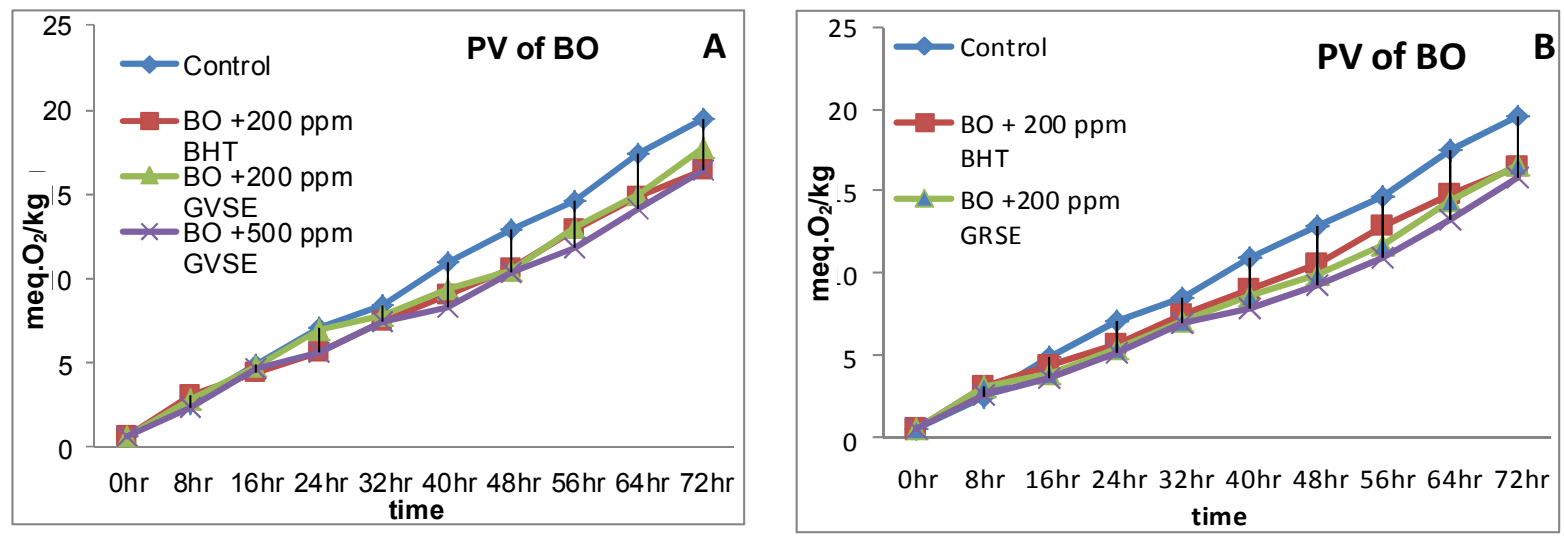

Fig. 1a,b. Effect of guava and grape seeds extracts at different concentration on the PV (meq. $\mathrm{O}_{2} / \mathrm{kg}$ oil) of blended oil during storage.

are more stable during the storage time, responsible for off-flavours and off-odours of edible oils. The $\mathrm{p}$-an $\mathrm{V}$ is the measure of the secondary product produced when the hydroperoxide decomposes to carbonyl, aldehydes, and other compounds. This stage leads to the rancid flavour of the oil (Laguerre et al., 2007). A lower $\mathrm{p}$-anV indicates a better quality of oil (Shahidi and Zong, 2005).

Fig. 2 a,b shows the changes recorded in $p$ anV during accelerated oxidation at $70^{\circ} \mathrm{C}$ for 72 $\mathrm{hr}$., as affected by supplementation with BHT, GVSE and GRSE. It can be observed that accelerated storage promoted rapid transformation to secondary products, which contributes to the off-flavours of BO. Addition of BHT and various levels of GVSE and GSE resulted in lower p-AV relative to the control sample. The highest level of GVSE and GRSE provides the best protection against secondary oxidation of oil samples. The active compounds present in the fruit seeds extract might deteriorate or decompose with storage time.

The increase of $\mathrm{p}$-an $\mathrm{V}$ of the treated samples showed a similar trend with that found for PV value. There were no significant differences between the p-an $\mathrm{V}$ of oil samples with the investigated extracts or BHT throughout storage at $70^{\circ} \mathrm{C}$ for 72 hours. The p-an $\mathrm{V}$ of the oil samples with the investigated extracts or BHT was about $60 \%$ of that of the control sample throughout the accelerated oxidation process. These data are in agreement with those reported by Iqbal and Bhanger (2007), Yim et al. (2013) and Mei et al. (2014). They found that the natural extracts showed a significant inhibitory effect against oxidation of refined oil.

\section{Measurement of TOTOX Value}

The total oxidation of oil sample can be calculated based on the determined PV and PanV values. These values are reported as TOTOX value. These values reflect the initial and later stages of the oil oxidation. It measures the primary product, hydroperoxide, and its breakdown product, aldehyde. Therefore, it provides a better estimation of the progressive oxidative deterioration of the oil. The lower TOTOX value indicates a higher quality of the oil (O'Keefe and Pike, 2010). 

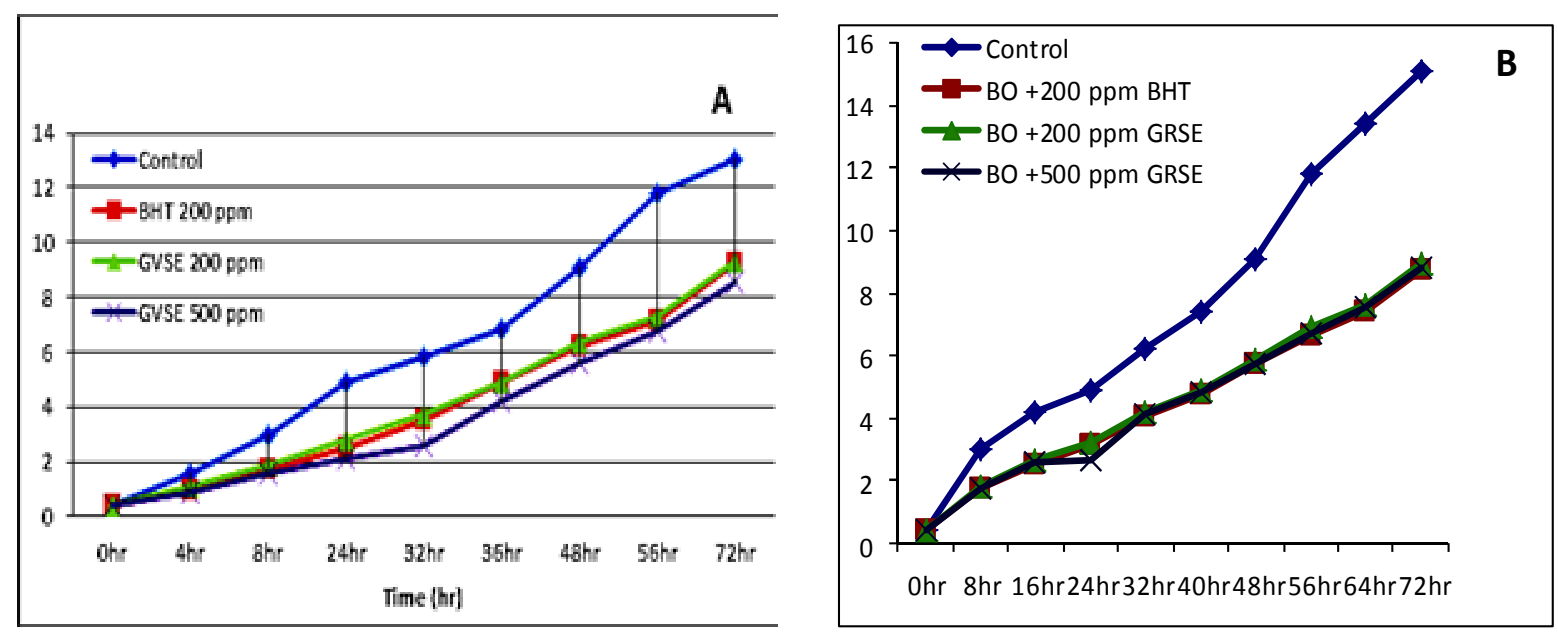

Fig. 2 a,b. Effect of guava and grape seeds extracts at different concentration on the p-anisidine value (P-an) of BO during accelerated storage
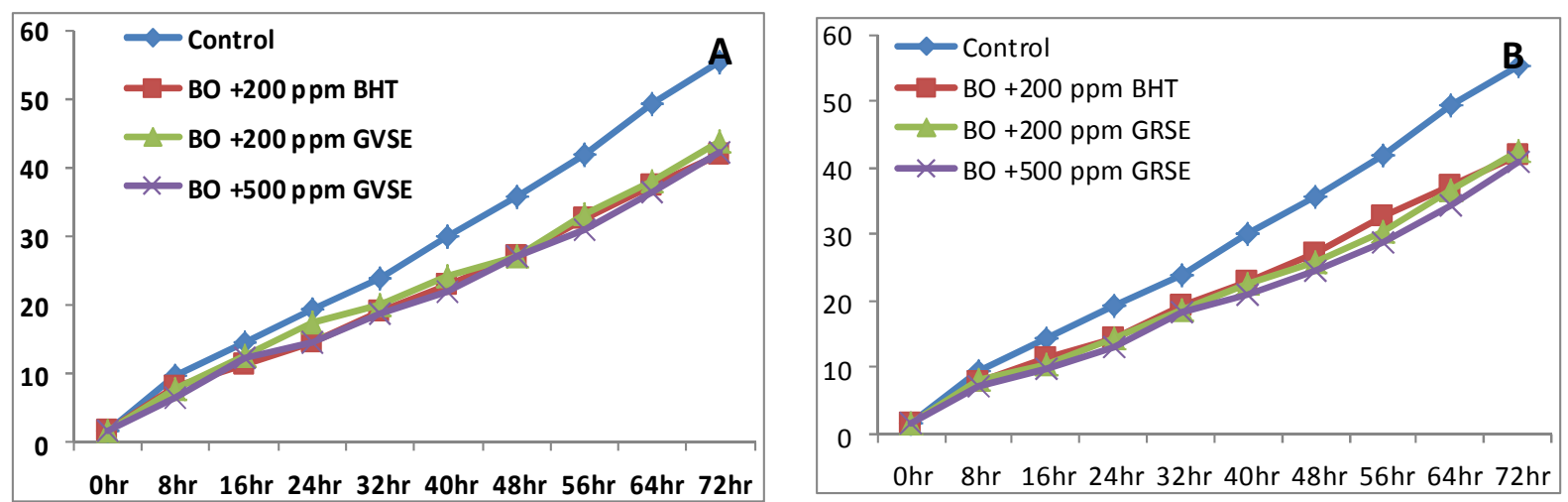

Fig. 3a,b. Effect of guava and grape seeds extracts at different concentration on the TOTOX of BO during accelerated storage

The TOTOX values of BO supplemented samples are as shown in Fig. 3 a,b. From these results it could be found that all the oil supplemented samples showed positive effects in inhibiting oxidative rancidity. The TOTOX value of all the investigated samples could be arranged in the following descending order as follows: control $>200 \mathrm{ppm}$ GVSE $>200 \mathrm{ppm}$ GRSE $>$ 200ppm BHT $>500$ ppm GVSE $>500$ ppm. The highest level of GRSE and GVSE had the best inhibitory effect on oil blend oxidation. The GVSE or GRSE at a level of $200 \mathrm{ppm}$ and500 ppm showed similar inhibiting effect on the lipid oxidation.

\section{Thiobarbituric Acid Reactive Substances (TBARS) Value}

TBARS values have been widely used as the marker for oxidative stress (Yim et al., 2013). The TBA values are expressed as milligrams of MA equivalents per kilogram of sample (Zhang et al., 2010).

The TBARS value of the BO supplemented samples and the control increased gradually from zero time to $72 \mathrm{hrs}$. The secondary products were determined to be lower at higher concentrations of the investigated antioxidants. These results are in accordance with that obtained by estimating P-anV. The TBARS values of $\mathrm{BO}$ samples stored at $70^{\circ} \mathrm{C}$ for 72 
hours are shown in Fig. 4 a,b. The results show that fruit seeds extracts were able to inhibit the formation of TBARS at all concentrations. These results are in accordance with those obtained in other studies. Iqbal and Bhanger (2007) and Iqbal et al. (2008) reported that addition of garlic extract and pomegranate peel at high concentrations had protective effects against oxidation of sunflower oil. The TBARS value decreased with the increase of extracts concentration. The inhibitory effect of both extracts was similar at each investigated concentration.

\section{Conclusion}

From the present study, it can be concluded that guava seeds and grape seeds extracts can stabilize blend of sunflower and soybean oils very effectively at all concentrations. They inhibit thermal deterioration of oil by improving its hydrolytic stability, inhibiting double bond conjugation and reducing the losses of polyunsaturated fatty acids. Grape seeds extract at concentration of $200 \mathrm{ppm}$ and $500 \mathrm{ppm}$ and guava seed extract at $200 \mathrm{ppm}$ have stabilization efficiency comparable to commonly-employed synthetic antioxidants BHT at their legal limit. This is in accordance with results of Mohdaly et al. (2010) who reported that in sunflower oil and soybean oil potato peels and sugar beet pulp extracts were more active than BHT. Grape seeds extract has a strong antioxidative effect during initial and final steps of oxidation in the dark, in an oven at $70^{\circ} \mathrm{C}$ for $72 \mathrm{hr}$., followed by guava seeds extract. Therefore, guava seeds and grape seeds extracts can be recommended as potent sources of antioxidants for the stabilization of food systems, especially unsaturated vegetable oils. The phenolic compounds appear to be responsible for the antioxidant activity of guava seeds and grape seeds extracts, although further studies are required to reveal whether they contain other antioxidative constituents. In addition, in vivo evidence and isolation of antioxidant components in guava seeds and grape seeds merit further investigation.
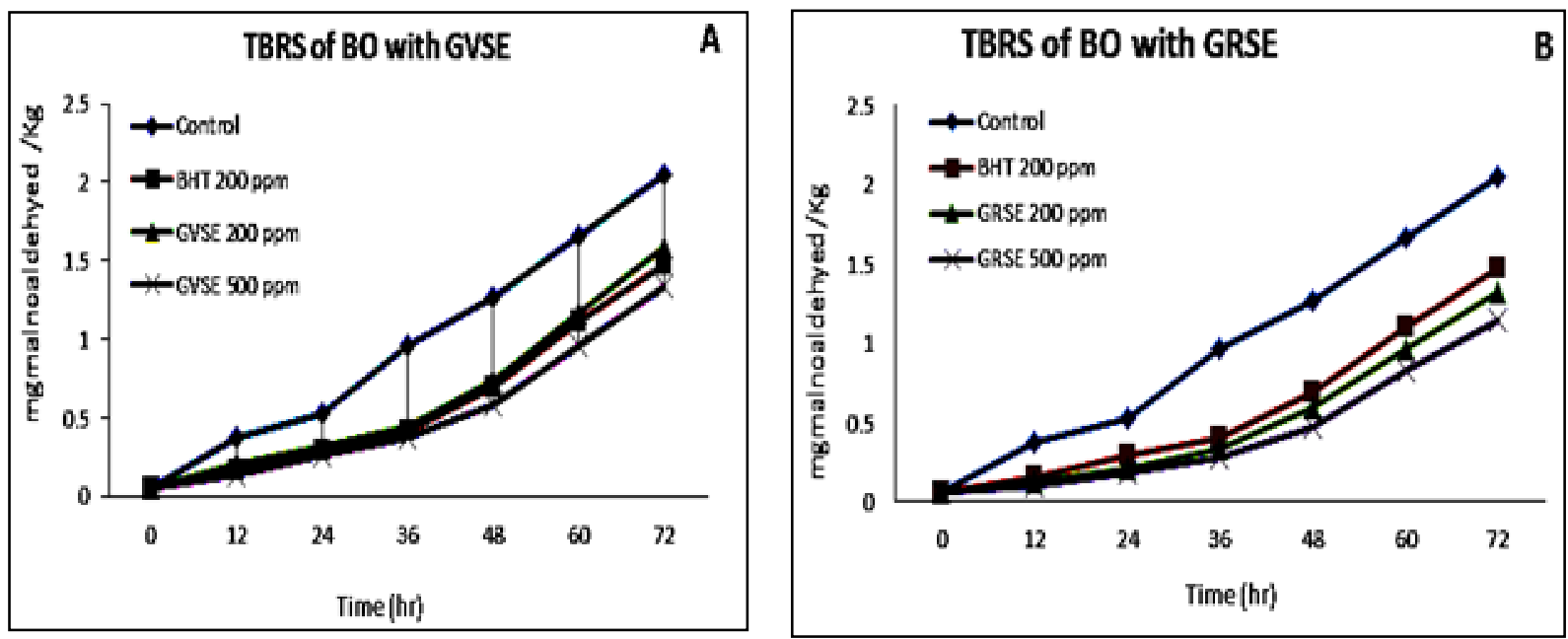

Fig. 4a,b. Effect of guava and grape seeds extracts at different concentration on the TBARS value (mg malonaldehyde/kg oil) of $\mathrm{BO}$ during accelerated storage 


\section{REFERENCES}

Adrar, S.A., B.L. Makhlouf, Y. Cadot, L.M. Haroune, F. Dahmoune, A. Makhoukhe and K. Madani (2015). Optimization of the recovery of phenolic compounds from Algerian grape by-products. Ind. Crops Prod., 177:123-132.

Ajila, C.M., K.A. Naidu, S.G. Bhat and R.U.J.S. Prasada (2007). Bioactive compounds and antioxidant potential of mango peel extract. Food Chem., 105: 982-988.

Aladedunye, F. and R. Przybylski (2013). Frying stability of high oleic sunflower oils as affected by composition of tocopherol isomers and linoleic acid content. Food Chem., 141: 2373-80.

AOAC (2005). Official Methods of Analysis $\left(18^{\text {th }}\right.$ Ed.). Association of Official Analytical Chemists, Washington, DC, USA.

AOCS (2007). Official Methods and Recommended Practices of the American Oil Chemists' Society, $6^{\text {th }}$ Ed.; AOCS: Champaign, IL, USA.

Artajo, L.S., M. Romero, J.R. Morelloa and M.J. Motilva (2006). Enrichment of refined olive oil with phenolic compounds: evaluation of their antioxidant activity and their effect on the bitter index. J. Agric. Food Chem., 54: 6079-6088.

Benzie, I.F.F. and Y.T. Szeto (1999). Total antioxidant capacity of by the ferric reducing/ antioxidant power assay. J. Agric. Food Chem., 47: 633-636.

Cadwallader, K.R. and C.L. Howard (1998). Analysis of aroma-activated components of light activated milk. In: Flavor Analysis: Developments in Isolation and Characterization. Mussinan, C.J., Morello, M.J. (Eds). ACS Symposium Series, 705. Washington: Ame. Chem. Soc., 343-358.

Castro-Vargas, H.I., L.I. Rodriquez-Verilla, S.R.S. Ferreira and F. Parado-Alfonso (2010). Extraction of phenolic fraction from guava seeds using super critical carbon dioxide and co-solvents. J. Supercritical fluids, $51: 319-329$.
David, P. (1970). The Chemical Analysis of Foods, $3^{\text {rd }}$ Ed., Churchill, London.

Einbond, L.S., K.A. Reynertson, X.-D. Luo, M.J. Basile and E.J. Kennelly (2004). Anthocyanin antioxidants from edible fruits. Food Chem., 4: 23-28.

El-Anany, A.M. (2007). Influence of pomegranate (Punica granatum) peel extract on the stability of sunflower oil during deepfat frying process. Electron. J. Food Plants Chem., 2: 14-19.

El-Anany, A.M. (2015). Nutritional composition, anti nutritional factors, bioactive compounds and antioxidant activity of guava seeds (Psidium myrtaceae) as affected by roasting processes. J. Food Sci. Technol., 52 (4): 2175-2183.

El-Baroty, G.S., M.F. Khalil and S.A. Mostafa (2014). Natural antioxidant ingredient from by- products of fruits. Ame. J. Agric. Biol. Sci., (3): 311-320.

El-Baroty, G.S., M.F. Khalil and S.H.A. Mostafa (2014). National antioxidant ingredients from by-products of fruits. Ame. J. Agric. and Biol. Sci., 9 (3): 311-320.

Erwin, W., G. Anna, H. Marzanna, H.J. Henryk, K. Jozef, M. Maria, M. Sylwia, R. Magdalena, S. Urszula and Z. Renata (2004). Oxidation of lipids in food. Pol. J. Food Nut. Sci., 13: 87-100.

FAOSTAT (2012). Available online: http:// faostat. fao.org/site/339/defut.aspx

Fontanari, G.G., M.C. Jaco, G.R. Souza, J.P. Batistuti, V.A. Neves, I.A. Pastre and F.L. Fertonanim (2008). DSC studies on protein isolate of guava seeds (Psidium guajava). J. Therm Anal Calorim., 93 (2): 397-402.

Frank, D.G. (2011). Vegetable Oils in Food Technology Composition, Properties and Uses. $2^{\text {nd }}$ Ed. A John Wiley and Sons, Ltd., Publication, B., 124-158.

Gallegos-Infante, J.A., N.E. Rocha-Guzman, R.F. Gonzalez-Laredo and J. Pulido-Alonso (2010). Effect of processing on the antioxidant properties of extracts from Mexican barley (Hordeum vulgare) Cultivar. Food Chem., 119 : 903-906 
Ghafoor, K., J. Park and Y.H. Choi (2010). Optimization of supercritical fluid extraction of bioactive compounds from grape (Vitis labrusca B.) peel by using response surface methodology. JT Innov. Food Sci. Emer. Technol., 11: 485-490.

Guo, X.D., C.S. Wu, Y.J. Ma, J. Parry, Y.Y. Xu, H. Liu and M. Wang (2012). Comparison of milling fraction of tartary buckwheat for their phenolic and antioxidant properties. Food Res. Int., 49: 53-59.

Halliwell, B. (1996). Antioxidants in human health and diseases. Annual Rev. Nut., 16: 33-50.

Iqbal, S. and M.I. Bhanger (2007). Stabilization of sunflower oil by garlic extracts during accelerated storage. Food Chem., $100: 246-$ 254.

Iqbal, S., S. Haleem, M. Akhtar, M. Zia-ul-Haq and J. Akbar (2008). Efficiency of pomegranate peel extracts in stabilization of sunflower oil under accelerated conditions. Food Res. J., 41: 194-200.

Jayaprakasha, G.J., T. Selvi and K.K. Sakariah (2003). Antibacterial and antioxidant activities of grape (Vitis vinifera) seed extracts. Food Res. Int., 36: 117-122.

Jung, C.H., H.M. Seog, I.W. Choi, M.W. Park and H.Y. Cho (2006). Antioxidant properties of various solvent extracts from wild ginseng leaves. LWT- Food Sci. Technol., 39 : 266274.

Kessler, M., G. Ubeaud and L. Jung (2003). Anti-and pro-oxidant activity of rutin and quercetin derivatives. J. Pharm. Pharmacol., 55: 131-142.

Kim, K.H., R. Tsao, R. Yang and S.W. Cui (2006). Phenolic acid profiles and antioxidant activities of wheat bran extracts and the effect of hydrolysis conditions. Food Chem., 95 (3):466-473

Laguerre, M., B. Chen, J. Lecomte, P. Villeneuve, D.J. McClements and E.A. Decker (2011). Antioxidant properties of chlorogenic acid and its alkyl esters in stripped corn oil in combination with phospholipids and/or water. J. Agric. and Food Chem., 59: 1036110366.
Laguerre, M., J. Lecomte and P. Villeneuve (2007). Evaluation of the ability of antioxidants to counteract lipid oxidation: Existing methods, new trends and challenges. Lipid Res., 46: 244-282.

Mansour, E.H. and A.H. Khalil (2000). Evaluation of antioxidant activity of some plant extracts and their application to ground beef patties. J. Food Chem., 69: 135-141.

Mariod, A.A., S.Y. Ahmed, S.I. Abdelwahab, S.F. Cheng, A.M. Eltom, S.O. Yagoub and S.W. Gouk (2012). Effects of roasting and boiling on the chemical composition, amino acids and oil stability of safflower seeds. Int. J. Food Sci. Technol., 47(8):1737-1743

Mattila, P., J. Astola and J. Kumpulainen (2000). Determination of flavonoids in plant material by HPLC with diode-array and electroarray detections. J. Agric. Food Chem., 48: 5834-5841.

Mei, W.S.C., A. Ismail, N.M. Esa, G.A. Akowuah, H.C. Wai and Y.H. Seng (2014). The effectiveness of rambutan (Nephelium lappaceum L.) extract in stabilization of sunflower oil under accelerated conditions. Ant., 3:371-386.

Mohamed G.F, S.S. Mohamed and S.T. Fakhriya (2011). Antioxidant, antimicrobial, and anticarcinogenic properties of Egyptian guava seed extracts. Nat. and Sci., 9 (11): 3241.

Mohdaly, A.A.A., M.A. Sarhan and A. Mahmoud (2010). Antioxidant efficacy of potato peels and sugar beet pulp extracts in vegetable oils protection. Food Chem., 123 : 1019-1026.

Naczk, M. and F. Shahidi (2004). Review: Extraction and analysis of phenolics in food. J. Chromatogr A., 1054: 95-111.

Nandeesh, K., R. Jyotsna and G. and Venkateswara Rao (2011). Effect of differently treated wheat bran on rheology, microstructure and quality characteristics of soft dough biscuits. J. Food Process. Preservat., 35: 79 -200 .

Nyam, K.L., M.M. Wong, K. Long and C.P. Tan (2013). Oxidative stability of sunflower oils supplemented with kenaf seeds extract, 
roselle seeds extract and roselle extract, respectively under accelerated storage. Int. Food Res. J., 20 : 695-701.

O'Keefe, S.F. and O.A. Pike (2010). Fat characterization. In Food Analysis, $4^{\text {th }}$ Ed.; Nielsen, S.S., Ed.; Spring. Sci. Bus. Media: New York, NY, USA, 239-260.

OIV (2015). International Organisation of Vine and Wine18 Rue d'Aguesseau75008 Paris, France

Okonogi, S., C. Duangrat, S. Anuchpreeda, S. Tachakittirungrod and S. Chowwanapoonpohn (2007). Comparison of antioxidant capacities and cytotoxicities of certain fruit peels. Food Chem., 103: 839-846.

Oyaizu, M. (1986). Studies on products of the browning reaction. Antioxidative activities of browning reaction products prepared from glucosamine. Eiyogaku Zasshi, 44: 307-315.

Pitchaon, M., S. Maitree and P. Rungnaphar (2007). Assessment of phenolic content and free radical-scavenging capacity of some Thai indigenous plants. Food Chem., 100: 1409-1418.

Poudel, P.R., H. Tamura, I. Kataoka and R. Mochioka (2008). Phenolic compounds and antioxidant activities of skins and seeds of five wild grapes and two hybrids native to Japan. J. Food Composition and Analysis, 21: 622-625.

Rodtjer, A., L.H. Skibsted and M.L. Andersen (2006). Antioxidative and prooxidative effect of extracts made from cherry liqueur pomace. Food Chem., 99: 6-14.

Saad, B., Y.S. Yong, A.N. Mohd, H. Noorhasani, S.M.A. Abdussalam, I.S. Muhammad, F.S. Saida, M.T. Khariuddin and A. Kamarudzaman (2007). Determination of synthetic phenolic antioxidants in food items using reversedphase HPLC. Food Chem., 105: 389-394.

Sanda, K.A., H.A. Grema, M.A. Geidam and Y.M. Bukar-Kolo (2011). Pharmacological aspects of (Psidium guajava):. Int. J. Pharm., $7: 316-324$

Shahidi, F. and Y. Zong (2005). Lipid Oxidation: Measurement Methods. Bailey's
Industrial Oil and Fat Products, $6^{\text {th }}$ Ed.; John Wiley and Sons, Inc.: Hoboken, NJ, USA, 357-385.

Sharma, H.K., R.S. Singhal and P.R. Kulkarni (1996). Blended oils-New Entrants in India, J. Sci. Indst Res., 4: 95-98.

Singleton, V.L. and J.A. Rossi (1965). Colorimetry of total phenolics with phosphomolybdicphosphotungstic acid reagents. Ame. J. Enol. Vitic., 16: 144-158.

Soong, Y.Y. and P.J. Barlow (2004). Antioxidant activity and phenolic content of selected fruit seeds. Food Chem., 88 (3): 411-417.

Sung, J. and J. Lee (2010). Antioxidant and antiproliferative of grape seeds from different cultivars. Food Sci. Biotechol., 19 (2): 321-326.

Uchoa-Thomaz, A.M.A., E.C. Sousa, J.O.B. Carioca, S.M. Morais, C.G. Alexandrino, P. A.T. Ferreir, S.P. Rodrigues, J.C.A. Thomaz, J.N. Silva and L.L. Rodrigues (2014). Chemical composition, fatty acid profile and bioactive compounds of guava seeds (Psidium guajava L.). Food Sci. and Techno. ISSN, 0101-2061.

Wojdyło, A., J. Oszmiański and R. Czemerys (2007). Antioxidant activity and phenolic compounds in 32 selected herbs. J. Food Chem., 105: 940 - 94

$\mathrm{Xu}, \mathrm{C}$., Y. Zhang, J. Wang and J. Lu (2010). Extraction, distribution and characterization of phenolic compounds and oils in grape seeds. Food Chem., 122 (3): 688-94.

Yang, J., T.E. Martinson and R.H. Liu (2009). Phytochemical profiles and antioxidant activities of winw grapes. Food Chem., 116: 332-339.

Yanishlieva, N.V. and E.M. Marinova (2001). Stabilisation of edible oils with natural antioxidants. Eur. J. Lipid Sci. Techol., 103 : 752-767.

Yim, H.S., F.Y. Chye, M.L. Liow and C.W. Ho (2013). Antioxidant potential of pleurotus porrigens extract and application in sunflower oil during accelerated storage. Chiang Mai J. Sci., 40: 34-48. 
Zambiazi, R.C., R. Przybylski, M.W. Zambiazi and C.B. Mendonca (2007). Fatty acid composition of vegetable oils and fats. B. CEPPA Curitiba., 25:111-120.

Zhang, Y., L. Yang, Y. Zu, X. Chen, F. Wang and F. Liu (2010). Oxidative stability of sunflower oil by carnosic acid compared with synthetic antioxidants during accelerated storage. Food Chem., 118: 656-662.

Zhishen, H., T. Mengcheng and W. Jianmin (1999). The determination of flavonoid contents in mulberry and their scavenging effects on superoxide radicals. Food Chem., 64: 555-559.

$$
\begin{aligned}
& \text { تأثير استخدام مستخلصات بذور الجوافة والعنب على الثبات الأوكسيدي لخليط زيتي } \\
& \text { دوار الشمس وفول الصويا } \\
& \text { طلعت محمد عبدالرحمن القاضي' - عباس عمر طليبة’ ـ محمد كمال عبدالرحمن' ـ سامي محمد أبو المعاطيخ } \\
& \text { اـ المعهد القومي للتغذية ـ وزارة الصحة ـ القاهرة ـ مصر } \\
& \text { r ـ قسم علوم الأغذية ـ كلية الزر اعة ـ جامعة الزقازيق ـ مصر }
\end{aligned}
$$

أجريت هذه الدراسة لتقييم تأثير مستخلص بذور كلا من الجو افة و العنب بالمقارنة مع مضاد الأكسدة الصناعي (BHT)

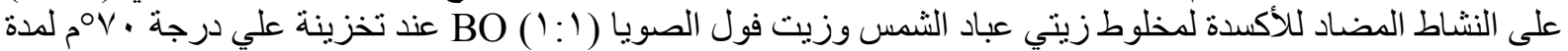



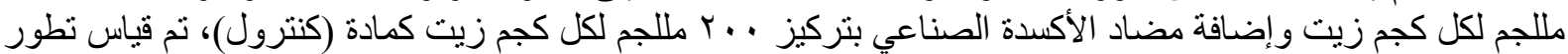

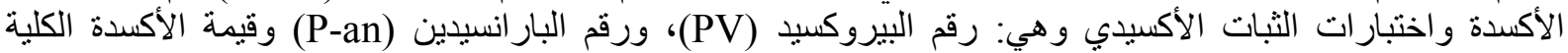

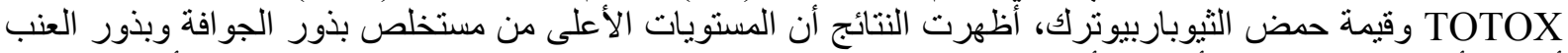

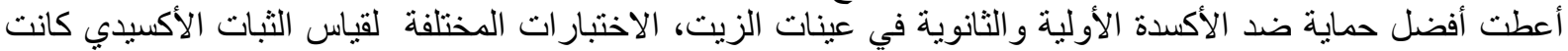

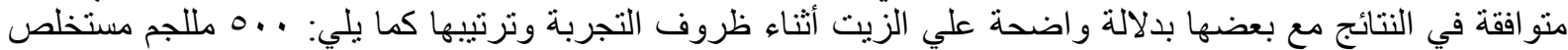

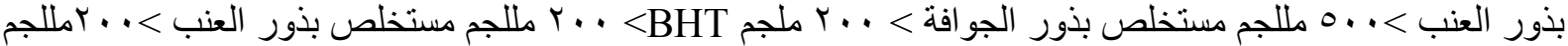

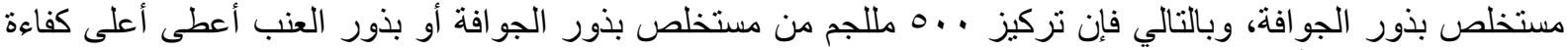

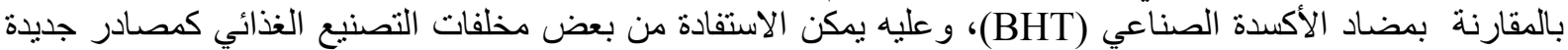

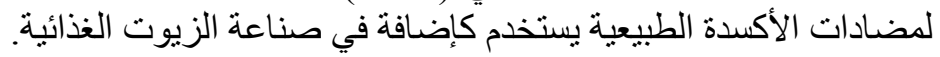

أستاذ الزيوت بمعهد تكنولوجيا الأغذية ـ مركز البحوث الزر اعية. أستاذ الصناعات الغذائية المتفر غ ـ كلية الزئ الزاعة - جامعة الزقازيق. 